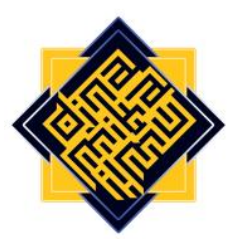

\title{
Examining the Need for Social Approval as a Predictor of Attitudes Towards the Teaching Profession
}

\author{
Mehtap Saraçoğlu \\ Faculty of Education, Siirt University, Turkey \\ e-mail:mehtapsarac@siirt.edu.tr \\ Mustafa Kahyaoğlu \\ Faculty of Education, Siirt University, Turkey \\ e-mail:mustafa.kahyaoglu56@gmail.com.tr
}

\section{Abstract}

The study aims to reveal the effect of the need for social approval on the prediction of attitudes towards the teaching profession, which has an important role in teachers' behaviors in educational settings. In this way, the effect and importance of the need for social approval such as sensitivity to the judgments of others, social retreat, and making a positive impression on others were examined. The research model was carried out according to the correlational survey model from quantitative research methods. The population of the study has consisted of university students studying at the Faculty of Education in a university located in the Southeastern Anatolia Region of Turkey, and the sample has consisted of 478 pre-service teachers. The sample of the study was determined according to the convenience sampling method. The data in the study were obtained by "Attitude scale towards the teaching profession" and "Social approval needs scale". Independent sample t-test, one-way ANOVA, and multiple regression analysis were used to analyze the data. As a result of the research, it was determined that the attitudes of pre-service teachers towards the teaching profession were "high" and social approval needs were "moderate". In the study, it was determined that the social approval need of the pre-service teachers is a significant predictor of the attitude towards the teaching profession. On the other hand, it was determined that the variables of sensitivity to the judgments of others and leaving a positive 
Mehtap Saraçoğlu \& Mustafa Kahyaoğlu

impression on others are significant predictors of attitudes towards the teaching profession, while the social retreat variable does not predict significantly.

Keywords: attitudes, pre-service teachers, social approval needs, teaching profession

\section{A. Introduction}

As Aristotle said: "Man is a social being by nature". Therefore, human beings need others to survive since the earliest days of history. Previously, this situation took place so as not to be left behind, to belong to a community, to be alone, and not to be fed to an animal, but today it occurs due to social concerns. Today, people need social approval in order not to be alone, not to be excluded, to be ignored and cared for.

According to Hofmann \& Di Bartolo (2010), people, as social beings, strongly need to be loved, valued, and approved by others. In the literature, the need for social approval is sometimes defined as a need and sometimes as a source of motivation. Accordingly, social approval is described as the tendency to be loved, admired, appreciated, to seek approval from others, or to seek praise (Hebert et al., 1997). It is stated that the need for social approval is related to gain the admiration and approval of others (Fehr \& Falk, 2002), to belong to a group, and to be applauded by a circle (Marar, 2004), a person wanting approval or avoiding not getting approved (Leite \& Beretvas, 2005). In this context, the need for social approval is defined as being very careful to be accepted socially and experiencing social anxiety to be adopted as a good individual (Chiba et al., 2009).

Crowne \& Marlowe (1964) stated that the individual needs to be perceived as a good person by the people around her/him and this requirement varies from person to person. Twenge \& Im (2007) define giving importance to the opinions of others, adapting to the society together with the concern for acceptability as a need for social approval. Social approval means that it is the object of admiration of others, while disapproval means that it is the object of disgust and contempt of others. Therefore, it is stated that while approval makes the individual feel proud and happy, disapproval makes them feel embarrassed and unhappy (Fehr \& Falk, 2002).

Larsen et al. (1976) stated that, regarding interpersonal interactions, an important part of human behavior is related to seeking approval. Moulton et al. (1998) emphasized that social approval is an important motivation for human behavior, and Crowne and Marlowe (1960) emphasized that getting approval from others is a motivating factor for the individual. Therefore, the desire to obtain approval or to prevent disapproval affects people's behavior (Fehr \& Falk, 2002).

Grams \& Rogers (1990) stated that people who need a high level of social approval experience intense anxiety about what other people think of them. Sosik \& Dinger (2007) stated that individuals with a high need for social approval are sensitive to the views of others and exhibit behaviors that they believe can gain approval, whereas individuals with low social approval needs have their own opinions and decisions which they think are more 
important than the approval of others. Individuals who need the approval of others tend to behave by the expectations of the group members they want to belong to, regardless of their wishes and needs (Özden, 2019). It is also stated that individuals seeking approval have harmonious, sympathetic, and cautious personality traits (Paulhus \& John, 1998).

West (2013) stated that people's feelings of value are based on social approval. Antony \& Swinson (2009) stated that perfectionists are individuals with extreme anxiety and they need high approval. Individuals with a high need for social approval are those who show excessive anxiety about the thoughts of others, whose feelings of value are based on social approval, who expect praise, are perfectionists, helpful, cannot say no, and have difficulty in rejecting. It can be said that individuals with a low need for social approval are individuals who are not easily affected by the thoughts of other individuals, who can reject the ideas they do not approve and have higher self-confidence. In addition, seeking approval/attention-seeking behaviors are explained as one of the characteristics of submissive individuals (West, 2013). Waiting for the approval of others leads them to have power over the individual seeking approval. The need for everyone's love and approval leaves the individual's value entirely to the approval of others, bringing them to live as if they are dependent on others. However, the individual needs to develop her/his values and criteria.

When the theories about the need for social approval are examined, it is seen that they are directly or indirectly related to the Murray needs list (Murray, 1938), Maslow's hierarchy of needs (Maslow, 1954), and the need for success (McClelland, 1961). According to Murray (1938) needs list social approval is closely related to intimacy and vanity. However, social approval is related to the need for belonging, love, and respect according to Maslow's (1954) hierarchy of needs theory. According to the need for achievement theory, the need for social approval plays a fundamental role in the establishment of social ties between people and the need for rapprochement (McClelland, 1961).

However, there are many studies in the literature regarding the need for social approval. Çiftçi et al. (2018) found that as the communication skills of pre-service teachers increased, their social approval needs to be decreased. Uslu et al. (2019), on the other hand, discussed the social approval needs of social studies pre-service teachers in terms of various variables. A significant difference was found in favor of females in the social withdrawal factor and favor of males in the sensitivity factor. Yalçınkaya et al. (2019) examined the need for social approval and well-being in adolescents in terms of some variables. A positive and significant relationship was found between adolescents' need for social approval and their level of well-being. Karaşar (2014) developed a measurement tool to measure the need for social approval and examined the relationships between the need for social approval and self-constructions, perfectionism, social anxiety, and happiness variables in university students. In the study, it was found that social anxiety, collectivistic self-construal, and perfectionism towards the self predicted the need for social approval. However, Huta \& Hawley (2010) stated in their study that the need for social approval was negatively related to feelings of hope, enthusiasm, humor, gratitude, and forgiveness. 
Crowl (2001) found that female teachers with a high need for social approval grades higher than teachers with low social approval needs.

The development level of a country depends on the quality of the teachers of that country. Teachers are called nation founders (builders). It is stated that if teachers do not have a positive attitude towards their profession, a good principal, magnificent buildings, solid infrastructure, or a good educational program does not work (Parvez \& Shakir, 2013). For this reason, there are many studies in the literature aiming to reveal the factors that affect attitudes towards the teaching profession (Arslan, 2019; Aydın \& Sağlam, 2012; Bakırcı, 2015; Bümen \& Ercan-Özaydın, 2013; Coşkun, 2020; Çetinkaya, 2007; Demirtaş et al., 2011; Engin \& Koç, 2014; Eroğlu, 2013; Gökçe, 2019; Gökçe \& Sezer, 2012; İşseveroğlu, 2019; Kaçar, 2018; Karademir \& Tezel, 2011; Karakuş, 2017; Karatekin et al., 2015; Nakip, 2015; Özcan, 2017; Özder et al., 2010; Şahin \& Şahin, 2017; Tatlı-Dalioğlu \& Adıgüzel, 2017; Terzi \& Tezci, 2007; Tufan, 2016; Yaşar-Ekici, 2014).

Arslan (2019), in her study on pre-service teachers, determined that pre-service teachers have a positive attitude towards the teaching profession. Çetinkaya (2007) found that the attitudes of Turkish pre-service teachers towards the teaching profession were higher in female students than in males. Aydın \& Sağlam (2012) stated that the attitudes of senior female students studying in different departments towards the teaching profession are more positive than male students, but the attitude point averages of pre-service teachers do not differ significantly according to their departments. Kaçar (2018) concluded that students with high academic achievement have high attitude levels. In the study of Özder et al. (2010), it was determined that the attitude scores of the pre-service teachers towards the teaching profession were high, and there was no difference in terms of gender.

Andronache et al. (2014) determined that educational sciences graduate students' attitude levels towards the teaching profession are medium. Aniruddha \& Mondal (2014) determined that $25 \%$ of education faculty students have a low attitude, $67 \%$ average and only $8 \%$ have a high attitude towards the teaching profession. Urton et al. (2014) and Colomeischi \& Colomeischi (2014) found a positive relationship between experience and attitude, concluding that the attitude increases as the experience process increases. Parvez \& Shakir (2013) found that there is no significant difference in the attitudes of female and male science and social science pre-service teachers towards the teaching profession.

It is stated that if future teachers have a positive attitude towards their profession, they will be able to develop their future students' intrinsic motivation for learning more easily, they will be able to communicate with them more efficiently, and they will be more involved in diversifying and personalizing learning situations (Andronache et al., 2014). A teacher's attitude towards his profession affects his behavior. It is very difficult for a teacher who does not enjoy his profession to be successful in his job. A good teacher with an appropriate attitude, behavior, and personality traits can motivate and inspire students. A teacher who has a positive attitude towards teaching is considered better and becomes a 
popular figure among students. Therefore, it is very important to examine the factors that can influence attitudes towards the teaching profession.

Therefore, teachers have important responsibilities in raising socially and psychologically healthy individuals in society. Teachers' attitudes towards their profession and their social approval needs will also affect the students they will raise. Teachers need to be aware of their role in the community and to cope with the demands of society. On the other hand, when the literature is examined, there are not enough studies examining the relationship between attitudes towards the teaching profession and the need for social approval. For this reason, it is thought that researching the attitudes of pre-service teachers, who will be the teachers of the future, towards the teaching profession and its relations will help determine the factors affecting the behavior of pre-service teachers. It will also be useful in developing the criteria to be used in the selection of teacher training programs. Measuring the pre-service teachers' need for social approval and examining the effects of the need for social approval on the attitude towards the teaching profession seem necessary to explain the motivations under pre-service teachers' behavior.

\section{Research Objectives}

The study aims to reveal the effect of social approval needs on the prediction of attitudes towards the teaching profession, which has an important role in teachers' behaviors in educational settings. In this context, the following research questions were sought.

1) What are the pre-service teachers' attitudes towards the teaching profession and the need for social approval?

2) Do pre-service teachers' attitudes towards the teaching profession and the need for social approval differ according to the variables of gender and type of department?

3) Are pre-service teachers' need for social approval significant predictors of attitudes towards the teaching profession?

\section{B. Research Methodology}

\section{Research Model}

The research was designed according to the correlational survey model. In the study, the pre-service teachers' need for social approval predicting their attitudes towards the teaching profession was examined. The dependent variable of the study is the attitudes towards the teaching profession, and the independent variable is the social approval needs of pre-service teachers.

\section{Research Population and Sample}

The population of the research consists of pre-service teachers studying at the Faculty of Education at a university in Turkey's Southeastern Anatolia Region. There are a total of 2450 pre-service teachers in the research population. Therefore, since it is not possible to reach the entire population due to time and economic reasons, the sample of the research was determined according to the convenience sampling method. The sample of the research consists of 478 pre-service teachers determined according to the 
convenience sampling method. As Yazıcıoğlu \& Erdoğan (2004) stated, 5\% error rate was taken into consideration while determining the sample number. Accordingly, it is stated that the sample that can represent a population between 2,000-2,500 should be between 278 and 333. Accordingly, it was accepted that a total of 478 pre-service teachers in the sample represented the population. The demographic information of the pre-service teachers is given in Table-1.

Table-1: Pre-service teachers' demographic characteristics

\begin{tabular}{|l|c|c|c|c|c|}
\hline The type of department studied & $\mathrm{n}$ & $(\%)$ & Gender & $\mathrm{n}$ & $(\%)$ \\
\hline $\begin{array}{l}\text { Computer Education and Instructional } \\
\text { Technology }\end{array}$ & 22 & 4.6 & Female & 307 & 64.2 \\
\hline Science Education & 47 & 9.8 & Male & 171 & 35.8 \\
\hline Mathematics Education & 77 & 16.1 & Total & 478 & 100 \\
\hline Primary School Teaching & 220 & 46 & & & \\
\hline Social Studies Teaching & 76 & 15.9 & & & \\
\hline Turkish Language Teaching & 36 & 7.5 & & & \\
\hline Total & 478 & 100 & & & \\
\hline
\end{tabular}

When the demographic characteristics of the sample in the study are examined, 307 $(64.2 \%)$ of the pre-service teachers are female and $171(35.8 \%)$ are male students. Information on the variable of the department where pre-service teachers are educated is given in Table 1. Accordingly, 22 (4.6\%) of the students are studying Computer Education and Instructional Technology, 47 (9.8\%) Science Education, 77 (16.1\%) Mathematics Education, 220 (46\%) Primary School Teaching, 76 (15.9\%) Social Studies Teaching and 36 (7.5\%) in Turkish Language Teaching.

\section{Data Collection Tools}

To obtain the data of the study, the "Need for Social Approval Scale", "Attitude Scale Towards the Teaching Profession" and the demographic information form, in which personal characteristics of the sample were collected, were used.

Demographic Information Form: In the demographic information form prepared by the researchers, there are question items related to the variables of gender, class, and the type of department in which the pre-service teachers study.

Need for Social Approval Scale: To determine the social approval needs of pre-service teachers "The Need for Social Approval Scale" developed by Karaşar (2014) was used. The scale consists of three sub-dimensions and 25 items.

- Sensitivity to Others' Judgments (9 items): It refers to the individuals' expectations of approval and appreciation by other individuals and their importance.

- Social Withdrawal (8 items): It expresses the fear of not being approved and getting rejected by others, the effort to make decisions according to the expectations of others, and the concealment of negative aspects.

- Leaving a Positive Impression (8 items): It refers to the feeling of worthlessness when one is not approved by others and when criticized. 
The scale, which is evaluated with five-point Likert grading, is evaluated between 1 (totally disagree) and 5 (completely agree). The scores of the scale range from 25 to 125 . The Cronbach's alpha internal reliability coefficient of the original scale developed by Karaşar (2014) was determined as 0.83 for sensitivity to the judgments of others, 0.80 for social withdrawal, 0.80 for making a positive impression on others, and 0.90 for the whole scale. In the study, the Cronbach's alpha internal reliability coefficient values of the scale were determined as 0.80 for sensitivity to the judgments of others, 0.67 for social withdrawal, 0.78 for making a positive impression on others, and 0.85 for the whole scale.

Attitude Scale Towards the Teaching Profession: To determine the attitudes of preservice teachers towards the teaching profession, the "Attitude Scale Towards the Teaching Profession" developed by Üstüner (2006) was used. The scale consists of one dimension and 34 items (for example, "Even the thought of being a teacher is attractive to me"). The scale, which is evaluated with five-point Likert grading, is evaluated between 1 (totally disagree) and 5 (completely agree). The scores of the scale range from 34 to 170 . The Cronbach alpha internal reliability coefficient value of the original scale developed by Üstüner (2006) was reported as 0.93. In the study, the Cronbach alpha internal reliability coefficient value of the whole scale was determined as 0.94 .

\section{Data Analysis}

The analysis of the data in the research was carried out with the SPSS 22.0 statistical package program. Skewness and Kurtosis values and the values of the $\mathrm{Q}-\mathrm{O}$ graph were examined to determine whether the data provided the assumption of normality. Values between " -.70 and -.18 " for the need for social approval and between ".08 and .50 " for the attitude towards the teaching profession and the values of Kurtosis and Skewness between -2 and +2 (Kalaycl, 2010) are accepted to show normal distribution. The Q-O graph shows the assumption of normality of the data with a 45 -degree angle. As is presented in Graphic-1.
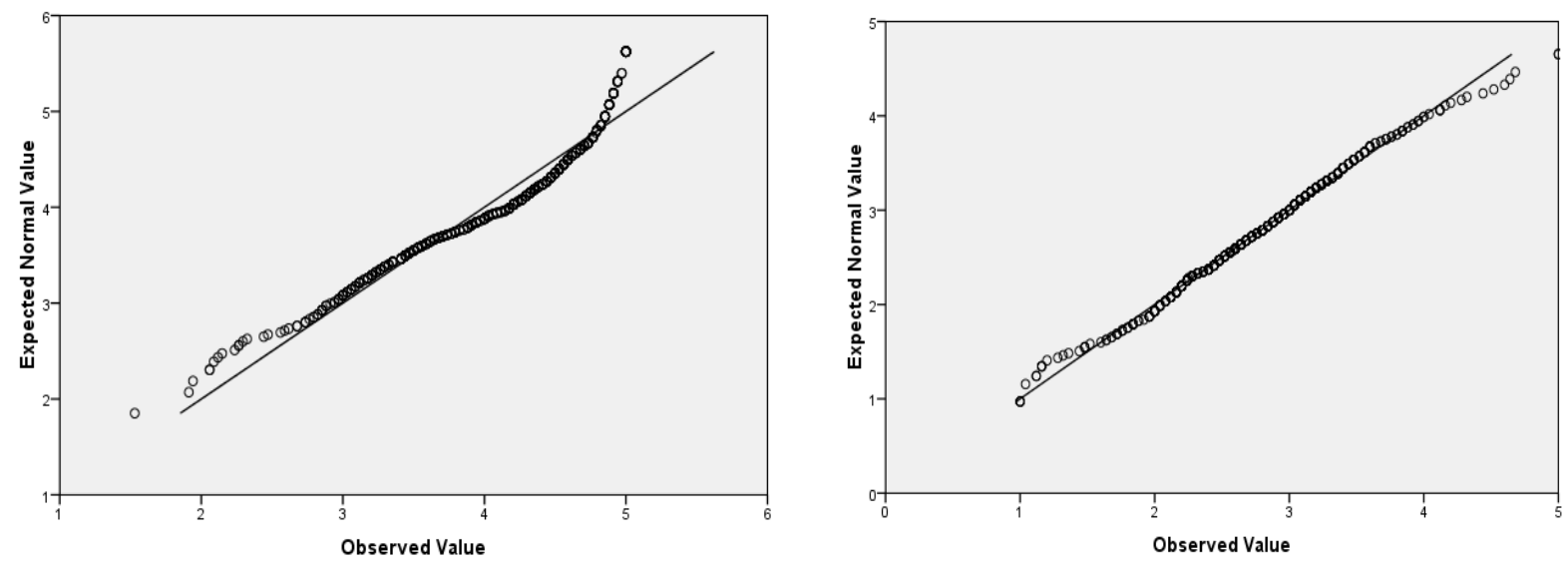

Graphic-1. a) Attitudes towards the teaching profession, b) need for social approval 
In the study, arithmetic mean scores were used to determine the social approval need of pre-service teachers and their level of attitude towards the teaching profession. However, the arithmetic means score values of the scales were interpreted as 1.00-1.80 "very low", 1.81-2.60 "low", 2.61-3.40 "medium", 3.41-4.20 "high" and 4.21-5.00 "very high". In the study, independent t-test and one-way ANOVA tests were used to determine whether the social approval needs of pre-service teachers and their attitudes towards the teaching profession differ significantly according to the variable of gender, class, and the type of department studied. As a result of the analysis, the effect size value was used to determine the degree of difference. The effect size value eta-square ( 12 ) reveals how much the independent variable explains the total variance in the dependent variable. The effect value varies between 0.00-1.00 and .01-.05 level is interpreted as "small", .06-.13 level as "medium" and .14 level as "large" effect size (Büyüköztürk, 2018). In the study, multiple regression analysis was used to determine the relationships between pre-service teachers' attitudes towards the teaching profession and their social approval needs.

\section{Findings}

Within the scope of the research, the findings of the relationship between the attitudes of the pre-service teachers towards the teaching profession and the need for social approval were examined based on the variables of gender and the department they studied. According to this;

\section{Findings Regarding the Attitudes of Pre-service Teachers towards the Teaching Profession and the Need for Social Approval}

In the research, the attitudes of the pre-service teachers towards the teaching profession and the arithmetic mean and standard deviation values regarding the need for social approval were examined and the findings obtained are given in Table-2.

Table-2: Findings regarding pre-service teachers' attitudes towards the teaching profession and the need for social approval

\begin{tabular}{|l|c|c|c|c|}
\hline Variable & $\mathrm{N}$ & $\mathrm{m}$ & $\overline{\mathrm{X}}$ & $\mathrm{SS}$ \\
\hline Sensitivity to the judgments of others & 478 & 9 & 3.47 & .85 \\
\hline Social withdrawal & 478 & 8 & 2.24 & .82 \\
\hline Leaving a positive impression on others & 478 & 8 & 2.51 & .87 \\
\hline Social approval needs & 478 & 25 & 2.77 & .66 \\
\hline Attitudes towards the teaching profession & 478 & 34 & 4.01 & .72 \\
\hline
\end{tabular}

m: number of items

According to Table 2, it was determined that the attitudes of the pre-service teachers towards the teaching profession ( $\overline{\mathrm{X}}=4.01)$ were "high", and their social approval needs $(\bar{X}=2.77)$ were "medium". However, in terms of the need for social approval subdimensions, it was determined that the highest arithmetic mean scores were in the "sensitivity to the judgments of others" ( $\overline{\mathrm{X}}=3.47)$ and the lowest in the "social withdrawal" $(\overline{\mathrm{X}}=2.24)$ dimension. 


\section{Findings of Pre-service Teachers' Attitude Towards the Teaching Profession and the Need for Social Approval According to the Gender Variable}

Independent sample t-test findings made to determine whether teacher pre-service teachers' attitude towards the teaching profession and their need for social approval differ according to gender variable are presented in Table-3.

Table-3: Findings regarding pre-service teachers' attitudes towards the teaching profession and the need for social approval according to the gender variable

\begin{tabular}{|c|c|c|c|c|c|c|c|c|}
\hline Variable & Group & $\mathrm{N}$ & $\bar{X}$ & Ss & sd & $\mathrm{T}$ & $\mathrm{p}$ & $\begin{array}{c}\text { effect size value } \\
\left(\eta^{2}\right)\end{array}$ \\
\hline \multirow{2}{*}{$\begin{array}{l}\text { Sensitivity to the } \\
\text { judgments of others }\end{array}$} & Male & 171 & 3.52 & .92 & \multirow{2}{*}{477} & \multirow{2}{*}{.898} & \multirow{2}{*}{.370} & \multirow{2}{*}{.002} \\
\hline & Female & 307 & 3.44 & .80 & & & & \\
\hline \multirow{2}{*}{ Social withdrawal } & Male & 171 & 2.42 & .91 & \multirow{2}{*}{477} & \multirow{2}{*}{3.643} & \multirow{2}{*}{$.000 *$} & \multirow{2}{*}{.027} \\
\hline & Female & 307 & 2.14 & .74 & & & & \\
\hline \multirow{2}{*}{$\begin{array}{l}\text { Leaving a positive } \\
\text { impression on others }\end{array}$} & Male & 171 & 2.45 & .87 & \multirow{2}{*}{477} & \multirow{2}{*}{-1.035} & \multirow{2}{*}{.301} & \multirow{2}{*}{.002} \\
\hline & Female & 307 & 2.54 & .86 & & & & \\
\hline \multirow{2}{*}{ Social approval needs } & Male & 171 & 2.83 & .68 & \multirow{2}{*}{477} & \multirow{2}{*}{1.406} & \multirow{2}{*}{.160} & \multirow{2}{*}{.004} \\
\hline & Female & 307 & 2.74 & .65 & & & & \\
\hline \multirow{2}{*}{$\begin{array}{l}\text { Attitudes towards the } \\
\text { teaching profession }\end{array}$} & Male & 171 & 3.94 & .74 & \multirow{2}{*}{477} & \multirow{2}{*}{-1.642} & \multirow{2}{*}{.101} & \multirow{2}{*}{.006} \\
\hline & Female & 307 & 4.05 & .70 & & & & \\
\hline
\end{tabular}

$* p<.05$

When table 3 is examined, it was determined that there is no significant difference between the attitude of the pre-service teachers towards the teaching profession according to the gender variable $\left(t_{477}=-1.642 ; p>.05\right)$ as a result of the independent sample t-test conducted in the study. Again, it was determined that there is no significant difference $\left(t_{477}=1.406 ; p>.05\right)$ between the pre-service teachers' need for social approval according to the gender variable. However, in the study, it was determined that there is a significant difference $\left(t_{477}=3.643 ; \mathrm{p}<.05\right)$ between the social withdrawal sub-dimensions of the pre-service teachers according to the gender variable and this difference is in favor of males. On the other hand, it was determined that there is no significant difference between the dimensions of the pre-service teachers' sensitivity to the judgments of others $\left(t_{477}=.898 ; p>.05\right)$ and leaving a positive impression on others ( $\left.t=-1.035 ; p>.05\right)$ according to the gender variable.

In the study, when the effect size values regarding the attitude towards the teaching profession and the need for social approval were examined according to the gender variable, it was determined that the attitude towards the teaching profession $(\eta 2=.006)$ and the need for social approval $(\eta 2=.004)$ were low between females and males. 


\section{Findings Regarding the Attitude Towards the Teaching Profession and the Need for Social Approval According to the Variable of the Department of Pre-service Teachers' Education}

Findings related to the arithmetic mean and standard deviation value of the preservice teachers according to the variable of the department in which they study and their need for social approval are given in Table-4.

Table-4: Findings regarding the attitude towards the teaching profession and the need for social approval according to the variable of the department in which the pre-service teachers are studying

\begin{tabular}{|c|c|c|c|c|}
\hline Variable & Group & $\mathrm{N}$ & $\overline{\mathrm{X}}$ & Ss \\
\hline \multirow{6}{*}{$\begin{array}{l}\text { Sensitivity to the } \\
\text { judgments of } \\
\text { others }\end{array}$} & Primary School Teaching & 220 & $3 \cdot 37$ & .93 \\
\hline & Science Education & 47 & 3.69 & .99 \\
\hline & Social Studies Teaching & 76 & 3.54 & .70 \\
\hline & Mathematics Education & 77 & $3 \cdot 50$ & .70 \\
\hline & Turkish Language Teaching & 36 & $3 \cdot 58$ & .81 \\
\hline & $\begin{array}{l}\text { Computer Education and Instructional } \\
\text { Technology }\end{array}$ & 22 & $3 \cdot 47$ & 57 \\
\hline \multirow{6}{*}{ Social withdrawal } & Primary School Teaching & 220 & 2.28 & .92 \\
\hline & Science Education & 47 & 2.39 & .69 \\
\hline & Social Studies Teaching & 76 & 2.15 & .70 \\
\hline & Mathematics Education & 77 & 2.24 & .74 \\
\hline & Turkish Language Teaching & 36 & 2.09 & .72 \\
\hline & $\begin{array}{l}\text { Computer Education and Instructional } \\
\text { Technology }\end{array}$ & 22 & 2.05 & 69 \\
\hline \multirow{6}{*}{$\begin{array}{l}\text { Leaving a positive } \\
\text { impression on } \\
\text { others }\end{array}$} & Primary School Teaching & 220 & 2.44 & .88 \\
\hline & Science Education & 47 & 2.60 & .83 \\
\hline & Social Studies Teaching & 76 & 2.50 & .87 \\
\hline & Mathematics Education & 77 & 2.62 & .83 \\
\hline & Turkish Language Teaching & 36 & 2.61 & .99 \\
\hline & $\begin{array}{l}\text { Computer Education and Instructional } \\
\text { Technology }\end{array}$ & 22 & 2.43 & .68 \\
\hline \multirow{6}{*}{$\begin{array}{l}\text { Social approval } \\
\text { needs }\end{array}$} & Primary School Teaching & 220 & 2.73 & .71 \\
\hline & Science Education & 47 & 2.92 & .64 \\
\hline & Social Studies Teaching & 76 & 2.76 & .59 \\
\hline & Mathematics Education & 77 & 2.82 & .62 \\
\hline & Turkish Language Teaching & 36 & 2.79 & .64 \\
\hline & $\begin{array}{l}\text { Computer Education and Instructional } \\
\text { Technology }\end{array}$ & 22 & 2.68 & .54 \\
\hline \multirow{6}{*}{$\begin{array}{l}\text { Attitudes towards } \\
\text { the teaching } \\
\text { profession }\end{array}$} & Primary School Teaching & 220 & 3.90 & .75 \\
\hline & Science Education & 47 & 4.21 & .66 \\
\hline & Social Studies Teaching & 76 & 4.18 & .63 \\
\hline & Mathematics Education & 77 & 3.88 & .70 \\
\hline & Turkish Language Teaching & 36 & $4 \cdot 37$ & .65 \\
\hline & $\begin{array}{l}\text { Computer Education and Instructional } \\
\text { Technology }\end{array}$ & 22 & 4.01 & .57 \\
\hline
\end{tabular}


When Table-4 is examined, it was determined that the highest arithmetic mean score regarding the attitudes of pre-service teachers towards the teaching profession was Turkish teaching $(\overline{\mathrm{X}}=4.37)$, and the lowest mathematics teaching $(\overline{\mathrm{X}}=3.88)$ department preservice teachers. When the need for social approval was examined, it was determined that the highest arithmetic average score was in science teaching $(\bar{X}=2.92)$ and the lowest was in pre-service teachers in computer education and instructional technology $(\overline{\mathrm{X}}=2.68)$. When the arithmetic mean scores of the sub-dimensions of the need for social approval are examined, the highest rate ( $\bar{X}=3.69$ and $\bar{X}=2.39$ ), in the dimensions of sensitivity to others' judgments and social withdrawal is seen in pre-service science teachers and leaving a positive impression on others is seen in the teacher pre-service teachers of mathematics education $(\overline{\mathrm{X}}=\mathbf{2 . 6 2})$ department. The lowest arithmetic mean scores were determined in the pre-service primary school teachers' $(\bar{X}=3.37)$, sensitivity to the judgments of others, social withdrawal, and leaving a positive impression on others in computer education and instructional technology pre-service teachers $(\bar{X}=2.05$ and $\bar{X}=\mathbf{2 . 4 3})$. In the study, a one-way analysis of variance (ANOVA) was conducted regarding the attitude towards the teaching profession and the need for social approval, according to the department variable. The findings obtained are given in Table- 5 .

Table-5: ANOVA findings on the attitudes of pre-service teachers towards the teaching profession and the need for social approval according to the department variable

\begin{tabular}{|c|c|c|c|c|c|c|c|}
\hline Variable & $\begin{array}{l}\text { Source of } \\
\text { variance }\end{array}$ & $\begin{array}{l}\text { Sum of } \\
\text { squares }\end{array}$ & Sd & $\begin{array}{l}\text { Mean of } \\
\text { squares }\end{array}$ & $\mathrm{F}$ & $\mathrm{p}$ & $\begin{array}{c}\text { Effect } \\
\text { size } \\
\text { value } \\
\left(\eta^{2}\right)\end{array}$ \\
\hline \multirow{3}{*}{$\begin{array}{l}\text { Sensitivity to the } \\
\text { judgments of others }\end{array}$} & Between groups & 5.123 & 5 & 1.025 & \multirow{3}{*}{1.422} & \multirow{3}{*}{.215} & \multirow{3}{*}{.015} \\
\hline & Within groups & 340.117 & 472 & .721 & & & \\
\hline & Total & 345.240 & 477 & & & & \\
\hline \multirow{3}{*}{ Social withdrawal } & Between groups & 3.731 & 5 & .746 & \multirow{3}{*}{1.101} & \multirow{3}{*}{.359} & \multirow{3}{*}{.012} \\
\hline & Within groups & 319.851 & 472 & .678 & & & \\
\hline & Total & 323.582 & 477 & & & & \\
\hline \multirow{3}{*}{$\begin{array}{l}\text { Leaving a positive } \\
\text { impression on others }\end{array}$} & Between groups & 2.802 & 5 & .560 & \multirow{3}{*}{.737} & \multirow{3}{*}{.596} & \multirow{3}{*}{.008} \\
\hline & Within groups & 359.028 & 472 & .761 & & & \\
\hline & Total & 361.830 & 477 & & & & \\
\hline \multirow{3}{*}{ Social approval needs } & Between groups & 1.846 & 5 & .369 & \multirow{3}{*}{.832} & \multirow{3}{*}{.527} & \multirow{3}{*}{.009} \\
\hline & Within groups & 209.450 & 472 & .444 & & & \\
\hline & Total & 211.296 & 477 & & & & \\
\hline \multirow{3}{*}{$\begin{array}{l}\text { Attitudes towards the } \\
\text { teaching profession }\end{array}$} & Between groups & 12.595 & 5 & 2.519 & \multirow{3}{*}{5.575} & \multirow{3}{*}{$.000 *$} & \multirow{3}{*}{.051} \\
\hline & Within groups & 232.128 & 466 & .498 & & & \\
\hline & Total & 244.723 & 471 & & & & \\
\hline
\end{tabular}

$* p<.05$

When Table 5 is examined, it was determined that there is a significant difference $\left(F_{(5}\right.$, $466)=5.575 ; p=.000$ ) between the attitude towards the teaching profession according to the variable of the department in which the pre-service teachers are studying. On the other hand, it was determined that there was no significant difference $\left(F_{(5,472)}=.832 ; p>.05 ; F_{(5}\right.$, 
472) $=1.422 ; p>.05 ; F_{(5,472)=1.101 ; p>.05 ;} F_{(5,472)=.737 ; p>.05)}$ between the overall and subdimensions of the social approval need the scale of pre-service teachers and the department variable in which they are studying. When the effect size values related to the general and sub-dimensions of the social approval needs of pre-service teachers in the study are examined, it was seen that the biggest effect value is "sensitivity to the judgments of others" ( $12=.015)$ and the smallest effect size value is in the dimension of "leaving a positive impression on others" (१2=.008).

\section{Findings Regarding the Degree of Pre-service Teachers' Need for Social Approval Predicting Attitudes Towards the Teaching Profession}

The findings of the multiple regression analysis conducted to determine the degree of predicting the attitude of pre-service teachers towards the teaching profession in the study are given in Table-6.

Table-6: Multiple regression analysis findings related to predicting the attitude towards the teaching profession

\begin{tabular}{lccccc}
\hline \multicolumn{1}{c}{ Variable } & $\mathrm{B}$ & $\mathrm{SH}$ & $\beta$ & $\mathrm{T}$ & $\mathrm{p}$ \\
\hline Constant & 3.496 & .145 & - & 24.137 & .00 \\
Sensitivity to the judgments of others & .284 & .040 & .33 & 7.128 & .00 \\
Social withdrawal & -.076 & .051 & -.08 & -1.480 & .13 \\
Leaving a positive impression on others & -.118 & .050 & -.14 & -2.369 & .01 \\
\hline
\end{tabular}

$\mathrm{R}=.32, \mathrm{R}^{2}=.10, \mathrm{~F}=18.563, \mathrm{p}<.01$

According to Table 6, it has been determined that the social approval need of the preservice teachers is a significant predictor of the attitude towards the teaching profession. It was determined that the need for social approval has a significant relationship with the attitude towards the teaching profession $(R=.32, p<.01)$. According to these findings, subdimensions of the need for social approval explain 10\% of the attitude towards the teaching profession. When the standardized regression coefficients were examined, it was determined that the "sensitivity to the judgments of others" $(\beta=.33)$ dimension was the most important in predicting the attitudes towards the teaching profession, followed by the dimensions of "leaving a positive impression on others" ( $\beta=-.14)$ and "social withdrawal" ( $\beta=-.08)$. When the $p$ values regarding the significance of the regression coefficients were examined, it was found that the "sensitivity to the judgments of others" dimension $(p<.05)$ and the dimension "leaving a positive impression on others" $(p<.05)$ were significant predictors, whereas "social withdrawal" ( $p>.05$ ) dimension was not found to be a significant predictor.

\section{Discussion}

In this study, it was aimed to examine the attitude of pre-service teachers towards the teaching profession and the need for social approval according to the variables of gender and the department they studied, and also to determine the degree to which the 
social approval need of the pre-service teachers predicted the attitude towards the teaching profession. In this study, it was determined that the attitude of pre-service teachers towards the teaching profession was at a "high (I agree)" level. According to Johnson \& Howell (2005), pre-service teachers' positive thoughts about the teaching profession also positively affect their professional life. In similar studies, it was stated that pre-service teachers' attitudes towards the teaching profession are generally at a "high (I agree)" level (Dikmen \& Tuncer, 2018; Dönmez \& Uslu, 2013; Serin et al., 2015; Yaylak, 2019). On the other hand, studies are indicating that pre-service teachers' attitudes towards the teaching profession are at a "low" level (Şahin \& Şahin, 2017). It is stated that attitudes are a complex tendency state that prepares the individual for behavior (BaykaraPehlivan, 2008). However, attitudes affect the continuity and order of individuals' feelings, thoughts, and behaviors. Accordingly, it can be said that the high level of attitudes of preservice teachers towards the teaching profession is important in terms of the education system exhibiting the behaviors expected from pre-service teachers.

In the research, it was determined that the social approval needs of the pre-service teachers were at the "medium" level. In a similar study, it was stated that pre-service teachers' need for social approval was at a "high" level (Uslu et al., 2019). However, when the sub-dimensions of pre-service teachers' need for social approval were examined, it was determined that the highest arithmetic mean score was "sensitivity to the judgments of others" and the lowest arithmetic means the score was "social withdrawal". The need for social approval is the state of anxiety faced by an individual's attention to the expectations or judgments of others or the desire to conform to other people's thoughts. Accordingly, it can be said that pre-service teachers attach a high level of importance to the judgments of others, whereas their tendency to social withdrawal, i.e., avoiding contact with others or isolating themselves from the environment, is low.

When the social approval needs of pre-service teachers according to gender variable were examined, it was found that there was no significant difference. In similar studies, Erözkan (2004, 2005), Karaşar (2014), Özden (2019), and Şavur (2020) found that the need for social approval does not differ significantly according to the gender variable. On the other hand, it was determined that there is a significant difference between the "social withdrawal" and gender variable, which is one of the sub-dimensions of the social approval need of pre-service teachers, and this difference is in favor of males. This situation can be interpreted as that men find rejection more embarrassing than women and feel the need to hide their negative aspects. Contrary to these studies, Çalış (2020) found that there is a significant difference in favor of females in the "positive impression" dimension, one of the sub-dimensions of need for social approval. In other words, the positive impression level of women is significantly higher than that of men. Ayan \& Ünsar (2015) also found that female students had higher levels of fear of being under the influence of others, being examined by others, and fear of making mistakes compared to male students.

When looking at the studies abroad examining the need for social approval by gender, it was seen that the need for social approval differs according to the gender variable, and the need for social approval was higher in females (Gary, 1967; MacDonald, 
1971; Masterson, 1971; Moran, 1967). Similarly, Tulkin et al. (1969) stated in their study that the need for social approval differs according to gender and this situation increases popularity in females and decreases in males.

It has been determined that there is no significant difference between pre-service teachers' attitudes towards the teaching profession and the gender variable. Contrary to this study, in Aydın \& Sağlam's (2012) study, the attitudes of senior students studying in different departments towards the teaching profession show a significant difference according to gender. The attitudes of senior year female students towards the teaching profession are more positive than male students. In other words, gender variable affects students' attitude scores. This result is supported by other studies on pre-service teachers (Aşkar \& Erden, 1987; Çapa \& Çil, 2000; Çapri \& Çelikkaleli, 2008; Durmuşoğlu et al., 2009). Similarly, in Erkuş's (2020) study, it is seen that the difference between the attitude scores of female teachers and the attitude scores of male teachers is significant in all dimensions.

In the study, it was determined that there is a significant difference between the variable of the department studied and the attitude towards the teaching profession. When the arithmetic means scores of the pre-service teachers regarding their attitudes towards the teaching profession according to the department variable were examined, it was determined that the highest attitude was found in Turkish teaching and the lowest in the Mathematics teaching department. This situation may be caused by many factors such as the program content of the department where the sampled students are studying, the attitude of the instructors, the physical environment, the status of their appointment rates to government schools, etc. Contrary to this situation, in the study of Aydın \& Sağlam (2012), Çapri \& Çelikkaleli (2008), Bozdoğan et al. (2007), the attitude score averages of pre-service teachers do not differ significantly according to their departments. In Erkuş's (2020) study, middle school teachers' attitudes towards their profession do not differ according to their branches.

In the study, it was determined that pre-service teachers' sensitivity to the judgments of others, social withdrawal, and leaving a positive impression on others had a significant relationship with pre-service teachers' attitudes towards the teaching profession. These variables explain $10 \%$ of the total variance in pre-service teachers' attitudes towards the teaching profession. Sensitivity to others' judgments and positive impression on others dimensions were found to be significant predictors of attitudes towards the teaching profession, whereas the social withdrawal variable did not predict significantly. Ellis \& Harper (2009) stated that when individuals strive for social approval, they live in line with the wishes and expectations of others. They pointed out that as individuals' desire for social approval increases, it becomes harder for other people to care about the person. This situation can cause people to be seen in a weak and undesirable situation. These explanations show that people who act in the direction of leaving a positive impression may decrease their interpersonal competence as a result of suppressing themselves in their interpersonal relationships. For example, the individual can overcome a conflict in which she is justified by putting her/his strength to work. However, when one always tends to be accepted or loved by others, in other words when 
one always tends to be a good boy, she/he can withdraw instead of showing her/his strength. In other words, she/he can refrain from a dispute she/he can resolve for the sake of not being misunderstood by others and leaving a positive impression (Baytemir et al., 2017).

\section{E. Conclusion}

As a result of the research, that the attitudes of the pre-service teachers towards the teaching profession were "high", and their social approval needs were "medium". It was determined that there is no significant difference between the pre-service teachers' attitudes towards the teaching profession according to the gender variable in the study. It was determined that there is no significant difference between the pre-service teachers' need for social approval according to the gender variable. It was determined that the highest arithmetic mean score regarding the attitudes of pre-service teachers towards the teaching profession was Turkish teaching, and the lowest mathematics teaching department pre-service teachers. When the need for social approval was examined, it was determined that the highest arithmetic average score was in science teaching and the lowest was in pre-service teachers in computer education and instructional technology teaching. It was determined that there is a significant difference between the attitude towards the teaching profession according to the variable of the department in which the pre-service teachers are studying. On the other hand, it was determined that there was no significant difference between the overall and sub-dimensions of the social approval need the scale of pre-service teachers and the department variable in which they are studying. It has been determined that the social approval need of the pre-service teachers is a significant predictor of the attitude towards the teaching profession. It was determined that the need for social approval has a significant relationship with the attitude towards the teaching profession.

\section{BIBLIOGRAPHY}

Andronache, D., Bocoş, M., Bocoş, V., \& Macri, C. (2014). Attitude towards teaching profession. Procedia-Social and Behavioral Sciences, 142, 628-632.

Aniruddha, C., \& Mondal, C. B. (2014). Attitude of prospective teachers towards teaching profession. American Journal of Social Sciences, 2(6), 120-125.

Antony, M. M., \& Swinson, R. P. (2009). When perfect isn't good enough: Strategies for coping with perfectionism. New Harbinger Publications.

Arslan, Ş. (2019). Öğretmen adaylarının öğretmenlik mesleğine ilişkin öz yeterlik inancı kaynakları ve öz yeterlik inançlarının öğretmenlik mesleğine yönelik tutumlarına etkisi (Unpublished master's dissertation). University of Bülent Ecevit, Zonguldak.

Aşkar, P., \& Erden, M. (1987). Öğretmen adaylarının öğretmenlik mesleğine yönelik tutum ölçeği. Çağdaş Eğitim Dergisi, 121, 8-11. 
Ayan, A., \& Ünsar, A. S. (2015). Olumsuz değerlendirilmekten korkma düzeylerinin belirlenmesi: Bir devlet üniversitesi öğrencileri üzerine araştırma. Manas Sosyal Araştırmalar Dergisi, 4(5), 263-277.

Aydın, R., \& Sağlam, G. (2012). Öğretmen adaylarının öğretmenlik mesleğine yönelik tutumlarının belirlenmesi (Mehmet Akif Ersoy Üniversitesi Örneği). Türk Eğitim Bilimleri Dergisi, 10(2), 257-294.

Bakırcı, Y. (2015). Beden eğitimi öğretmen adaylarının öğretmenlik mesleğine yönelik tutumlarının incelenmesi (Unpublished master's dissertation). University of Aksaray, Aksaray.

Baykara-Pehlivan, K. (2008). Sınıf öğretmeni adaylarının sosyo-kültürel özellikleri ve öğretmenlik mesleğine yönelik tutumları üzerine bir çalışma. Mersin Üniversitesi Eğitim Fakültesi Dergisi, 4(2), 151-168.

Baytemir, K., Karaşar, B., \& Ögülmüş, S. (2017). Ebeveyne bağlanma ve sosyal onay ihtiyacının kiş̧ilerarası yeterliği yordayıcılığı. Mersin Üniversitesi Eğitim Fakültesi Dergisi, 13(3), 949-960.

Bozdoğan, A. E., Aydın, D., \& Yıldırım, K. (2007). Öğretmen adaylarının öğretmenlik mesleğine ilişkin tutumları. Ahi Evran Üniversitesi Kırşehir Eğitim Fakültesi Dergisi, 8(2), $83-97$.

Bümen, N. T., \& Ercan-Özaydın, T. (2013). Adaylıktan göreve öğretmen özyeterliği ve öğretmenlik mesleğine yönelik tutumlardaki değişimler. Eğitim ve Bilim, 38(169), 109125 .

Büyüköztürk, Ş. (2018). Sosyal bilimler için veri analizi el kitabı: Istatistik, araştırma deseni, SPSS uygulamaları ve yorum (24. Baskı). Pegem Akademi Yayıncılık.

Chiba, T., Iketani, S., Han, K., \& Ono, A. (2009). A comprehensive model of anxiety in gift giving. International Review of Business Research Papers, 5(4), 322-334.

Colomeischi, A. A., \& Colomeischi, T. (2014). Teachers' attitudes towards work in relation with emotional intelligence and self-efficacy. Procedia-Social and Behavioral Sciences, $159,615-619$.

Coşkun, O. C. (2020). Öğretmen adayları pedagojik inançlarının, öğretmen öz-yeterlilik ve öğretmenlik mesleğine yönelik tutumları açısından incelenmesi (Unpublished master's dissertation). University of Balıkesir, Balıkesir.

Crowl, T. K. (2001). Grading behavior and teacher's need for social approval. Education, 104(3), 291-295.

Crowne, D. P., \& Marlowe, D. (1960). A new scale of social desirability independent of psychopathology. Journal of Consulting Psychology, 24, 349-354.

Crowne, D. P., \& Marlowe, D. (1964). The approval motive. John Wiley \& Sons.

Çalış, M. (2020). Sosyal medya kullanımı ile sosyal onay ihtiyacı ve kaygı düzeyleri arasındaki ilişki (Unpublished master's dissertation). University of İstanbul Gelişim, İstanbul.

Çapa Y., \& Çil, N. (2000). Öğretmen adaylarının öğretmenlik mesleğine yönelik tutumlarının farklı değişkenler açısından incelenmesi. Hacettepe Üniversitesi Eğitim Fakültesi Dergisi, 18, 69-73. 
Çapri, B., \& Çelikkaleli, Ö. (2008). Öğretmen adaylarının öğretmenliği ilişkin tutum ve mesleki yeterlik inançlarının cinsiyet, program ve fakültelerine göre incelenmesi. İnönü Üniversitesi Eğitim Fakültesi Dergisi, 9(15), 33-53.

Çetinkaya, R. (2007). Türkçe öğretmeni adaylarının yeterlilik algıları ve öğretmenlik mesleğine yönelik tutumları (Unpublished master's dissertation). University of Selçuk, Konya.

Çiftçi, M., Akan, D., Yıldırım, I.., \& Yalçın, S. (2018). Öğretmen adaylarının iletişim becerileri ile sosyal onay ihtiyaçları arasındaki ilişkinin incelenmesi. M. Keha and Z. Alimgereyev (Eds.) UMTEB IV. Uluslararası Mesleki ve Teknik Bilimler Kongresi Tam Metin Kitabı (pp. 294-303) içinde. Erzurum: Iksad Uluslararası Yayınevi.

Demirtaş, H., Cömert, M., \& Özer, N. (2011). Öğretmen adaylarının özyeterlik inançları ve öğretmenlik mesleğine ilişkin tutumları. Eğitim ve Bilim Dergisi, 36(159), 96-111.

Dikmen, M., \& Tuncer, M. (2018). Öğretmenlik mesleğine yönelik tutumun çeşitli değişkenler açısından incelenmesi. Harran Education Journal, 3(1), 24-38.

Dönmez, C., \& Uslu, S. (2013). Sosyal bilgiler öğretmen adaylarının öğretmenlik mesleğine yönelik tutumları. Türk Ĕgitim Bilimleri Dergisi, 11(1), 42-63.

Durmuşoğlu, M. C., Yanık, C., \& Akkoyunlu, B. (2009). Türk ve Azeri öğretmen adaylarııın öğretmenlik mesleğine yönelik tutumları. Hacettepe Üniversitesi Eğitim Fakültesi Dergisi, 36,76-86.

Ellis, A., \& Harper, R. A. (2009). Akılcı yaşam kılavuzu. (S. Kunt-Akbaş, Trans.). HYB Yayıncilık.

Engin, G., \& Koç, G. Ç. (2014). Öğretmen adaylarının öğretmenlik mesleğine yönelik tutumları (Ege Üniversitesi eğitim fakültesi örneği). Türkiye Sosyal Araştırmalar Dergisi, 18(2), 153-167.

Erkuş, M. (2020). Öğretmenlerin öğretmenlik mesleğine ve alternatif ölçme-değerlendirmeye yönelik tutumlarının incelenmesi (Unpublished master's dissertation). University of İnönü, Malatya.

Eroğlu, C. (2013). Beden eğitimi öğretmen adaylarının özyeterlikleri ve öğretmenlik mesleğine yönelik tutumları (Unpublished master's dissertation). University of Aksaray, Aksaray.

Erözkan, A. (2004). Üniversite öğrencilerinin kişilerarası duyarlılıkları ile reddedilme duyarlııklarının bazı değişkenlere göre incelenmesi. Gazi Üniversitesi Kırşehir Eğitim Fakültesi, 5(2), 85-98.

Erözkan, A. (2005). Üniversite öğrencilerinin kişilerarası duyarlııı ve depresyon düzeylerinin bazı değişkenlere göre incelenmesi. Muğla Üniversitesi SBE Dergisi, 14, 130-155.

Fehr, E., \& Falk, A. (2002). Psychological foundations of incentives. Center for Economic Studies \& Ifo Institute for Economic Research CESifo Working Paper No. 714. Institute for the Study of Labor IZA Working Paper No. 507.

Gary, M. (1967). Ordinal position and approval motivation. Journal of Consulting Psychology, 31(3), 319-320.

Gökçe, A. (2019). Dördüncü sınıf öğretmen adaylarının öğretmenlik mesleğine yönelik tutumlarının çeşitli değişkenler açısından incelenmesi (Unpublished master's dissertation). University of Akdeniz, Antalya. 
Mehtap Saraçoğlu \& Mustafa Kahyaoğlu

Gökçe, F., \& Sezer, G. O. (2012). Öğretmen adaylarının öğretmenlik mesleğine yönelik tutumları (Uludağ üniversitesi örneği). Uludağ Üniversitesi Eğitim Fakültesi Dergisi, 25(1), 1-23.

Grams, W. C., \& Rogers, R. W. (1990). Power and personality: Effects of machiavellianism, need for approval and motivation on use of influence tactics. The Journal of General Psychology, 117(1), 71-82.

Hebert, J. R., Ma, Y., Clemow, L., Ockene, I. S., Saperia, G., Stanek, E.J., Merriam, P. A., \& Ockene, J. K. (1997). Gender differences in social desirability and social approval bias in dietary self-report. American Journal of Epidemiology, 146(12), 1046-1055.

Hofmann, S. G., \& DiBartolo, P. M. (2010). Introduction: toward an understanding of social anxiety disorder. S. G. Hofmann., P. M. DiBartolo (Eds.). Social anxiety: clinical, developmental, and social perspectives. Elsevier/Academic Press.

Huta, V., \& Hawley, L. (2010). Psychological strengths and vulnerabilities: are they two ends of the same continuum or do they have independent relationships with wellbeing and ill-being? Journal of Happiness Studies, 71-93.

İşseveroğlu, E. (2019). Müzik öğretmenliği bölümü öğrencilerinin öğretmenlik mesleğine yönelik tutumları (Unpublished master's dissertation). University of Muğla Sıtkı Koçman, Muğla.

Johnson, G., \& Howell, A. (2005). Attitude toward instructional technology following required versus optional webctusage. Journal of Technology and Teacher Education, $13(4), 643-654$.

Kaçar, R. (2018). Sosyal bilgiler öğretmen adaylarının öğretmenlik mesleğine yönelik tutum ve öz-yeterlik algıları (Unpublished master's dissertation). University of Fırat, Elazığ.

Kalaycı, Ş. (2010). SPSS uygulamalı çok değişkenli istatistik teknikleri. Asil Yayın Dağıtım.

Karademir, E., \& Tezel, Ö. (2011). Öğretmen adaylarının öğretmenlik mesleğine yönelik tutum ve endişelerinin incelenmesi. Education Sciences, 6(3), 2005-2018.

Karakuş, İ. (2017). Öğretmen adaylarının öz-yeterlik inançları ile öğretmenlik mesleğine yönelik tutumları arasındaki ilişkinin incelenmesi (Unpublished master's dissertation). University of Kahramanmaraş Sütçü İmam, Kahramanmaraş.

Karasar, N. (2012). Bilimsel araştırma yöntemleri. Nobel Yayınları.

Karaşar, B. (2014). Sosyal onay ihtiyacının çeşitli değişkenler açısından incelenmesi (Unpublished doctoral dissertation). University of Ankara, Ankara.

Karatekin, K., Merey, Z., \& Keçe, M. (2015). Sosyal bilgiler öğretmen adaylarının öğretmenlik mesleğine yönelik tutumları. Yüzüncü Yıl Üniversitesi Eğitim Fakültesi Dergisi, 12(1), 70-96.

Larsen, K. S., Martin, H. J., Ettinger, R. H., \& Nelson, J. (1976). Approval seeking, social cost and aggression: A scale and some dynamics. Journal of Psychology, 94, 3-11.

Leite, W. L., \& Beretvas, S. N. (2005). Validation of scores on the marlowe-crowne social desirability scale and the balanced inventory of desirable responding. Educational and Psychological Measurement, 6(1), 140-154.

MacDonald, A. P. (1971). Birth order and personality. Journal of Consulting and Clinical Psychology, 36(2), 171-176. 
Marar, Z. (2004). Mutluluk paradoksu: Özgürlük ve onaylanma. (S. Çağlayan, Trans.). Kitap Yayınevi.

Maslow, A. (1954). Motivation and personality. Longman Inc.

Masterson, M. L. (1971). Family structure variables and need approval. Journal of Consulting and Clinical Psychology, 36(1), 12-13.

McClelland, D. C. (1961). The achieving society. Van Nostrand.

Moran, G. (1967). Ordinal position and approval motivation. Journal of Consulting Psychology, 31(3), 319-320.

Moulton, P., Moulton, M., \& Roach, S. (1998). Eating disorders: A means for seeking approval? Eating Disorders: The Journal of Treatment \& Prevention, 6(4), 319-327.

Murray, H. A. (1938). Explorations in personality. Oxford University Press.

Nakip, C. (2015). Öğretmen adaylarının öğretmenlik mesleğine yönelik öz-yeterlik inançları ile öğretmenlik mesleğine yönelik tutumları arasındaki ilişki (Unpublished master's dissertation). University of Abant İzzet Baysal, Bolu.

Özcan, C. (2017). Fen bilgisi öğretmen adaylarının mesleki öz-yeterlik inançları ve öğretmenlik mesleğine yönelik tutumları ile ilköğretim bölümlerinin karşılaştırılması (Unpublished master's dissertation). University of Akdeniz, Antalya.

Özden, A. T. (2019). Tüketici yenilikçiliği ve sosyal onay ihtiyacı arasındaki ilişkinin incelenmesi üzerine bir araştırma. İşletme Araştırmaları Dergisi, 11(3), 1537-1558.

Özder, H., Konedralı, G., \& Zeki, C. P. (2010). Öğretmen adaylarının öğretmenlik mesleğine yönelik tutumlarının çeşitli değişkenler açısından incelenmesi. Kuram ve Uygulamada Eğitim Yönetimi, 16(2), 253-275.

Parvez, M., \& Shakir, M. (2013). Attitudes of prospective teachers towards teaching profession. Journal of Education and Practice, 4(10), 172-178.

Paulhus, D. L., \& John, O. P. (1998). Egoistic and moralistic biases in self-perception: The interplay of self-deceptive styles with basic traits and motives. Journal of Personality, 66(6), 1025-106o.

Serin, M. K., Güneş, A. M., \& Değirmenci, H. (2015). Sınıf öğretmenliği bölümü öğrencilerinin öğretmenlik mesleğine yönelik tutumları ile mesleğe yönelik kaygı düzeyleri arasındaki ilişki. Cumhuriyet International Journal of Education, 4(1), 21-34.

Sosik, J. J., \& Dinger, S. L. (2007). Relationships between leadership style and vision content: The moderating role of need for social approval, self-monitoring, and need for social power. The Leadership Quarterly, 18, 134-153.

Şahin, C., \& Şahin, S. (2017). Öğretmen adaylarının öğretmenlik mesleğine yönelik tutumları, öz-yeterlik inançları ve öğrenciyi tanıma düzeyleri. Türk Eğitim Bilimleri Dergisi, 15(2), 224-238.

Şavur, I. (2020). Üniversite öğrencilerinde sosyal onay ihtiyacı: Yetiştirilme tutumlarına yönelik algı ve benlik kurgusunun rolü (Unpublished master's dissertation). University of Hasan Kalyoncu, Gaziantep.

Tatlı-Dalioğlu, S., \& Adıgüzel, O. C. (2017). Öğretmen adaylarının olası benlikleri, özyeterlik inançları ve öğretmenliğe ilişkin tutumları arasındaki ilişki. Mersin Üniversitesi Eğitim Fakültesi Dergisi, 13(2), 487-496.

Dinamika Ilmu, Volume 21(2), 2021 
Terzi, A. R., \& Tezci, E. (2007). Necatibey eğitim fakültesi öğrencilerinin öğretmenlik mesleğine ilişkin tutumları. Kuram ve Uygulamada Eğitim Yönetimi, 52, 593-614.

Tufan, Z. (2016). Fen bilgisi öğretmenlerinin, öğretmenlik mesleğine yönelik tutumları ile özyeterlilikleri arasındaki ilişki (Unpublished master's dissertation). University of İstanbul Aydın, İstanbul.

Tulkin, S. R., Muller, J. P., \& Conn, L. K. (1969). Need for approval and popularity: Sex differences in elementary school students. Journal of Consulting and Clinical Psychology, 33(1), 35-39.

Twenge, J. M., \& Im, C. (2007). Changes in the need for social approval, 1958-2001. Journal of Research in Personality, 41(1), 171-189.

Urton, K., Wilbert, J., \& Henneman, T. (2014). Attitudes towards inclusion and self-efficacy of principals and teachers. Learning Disabilities: A Contemporary Journal, 12(2), 151168.

Uslu, S., Yazıcı, K., \& Geçgel, Ş. (2019). Sosyal bilgiler öğretmen adaylarının sosyal onay ihtiyaçlarının çeşitli değişkenler açısından incelenmesi. Kırşehir Eğitim Fakültesi Dergisi, 20(3), 1120-1147.

Üstüner, M. (2006). Öğretmenlik mesleğine yönelik tutum ölçeğinin geçerlik ve güvenirlik çalışması. Kuram ve Uygulamada Eğitim Yönetimi, 45, 109-127.

West, H. (2013). Fear is not a mental disorder: Or what is really wrong with the dsm. Retrieved 01 Şubat, 2021 from http://www.harperwest.co/fear-is-not-a-mentaldisorderor-what-is-really-wrong-with-the-dsm/

Yalçinkaya, M., Taner, M., \& Demirci, E. (2019). Ergenlerde sosyal onay ve iyilik hallerinin incelenmesi. Folklor/Edebiyat, 25(97), 716-729.

Yaşar-Ekici, F. (2014). Öğretmen adaylarının öğretmenlik mesleğine yönelik tutumlarının çeşitli değişkenler açısından incelenmesi (İstanbul Sabahattin Zaim Üniversitesi Örneği). Uluslararası Sosyal Araştırmalar Dergisi, 7(35), 658-665.

Yaylak, E. (2019). Sosyal bilgiler öğretmen adaylarının öğretmenlik mesleğine yönelik tutumlarının incelenmesi. Uluslararası Sosyal Bilimlerde Yeni Yaklaşımlar Dergisi, 3(1), 25-40.

Yazıcıoğlu, Y., \& Erdoğan, S. (2004). SPSS uygulamalı bilimsel araştırma yöntemleri. Detay Yayıncılık. 